\title{
日本における薬剤師需給の予測に関する研究
}

\author{
山本展 裕, ${ }^{a}$ 内山 充*,b
}

\section{A Prediction Study on the Supply of and Demand for Pharmacists in Japan}

\author{
Nobuhiro YAMАмото ${ }^{a}$ and Mitsuru UCHIYAMA*,b \\ Ministry of Health, Labour and Welfare, ${ }^{a}$ 1-2-2, Kasumigaseki, Chiyoda-ku, Tokyo 100-8916, \\ Japan and Japan Pharmacists Education Center, ${ }^{b}$ Toranomon 19 Mori Bldg., 1-2-20, \\ Toranomon, Minato-ku, Tokyo 105-0001, Japan
}

(Received September 14, 2001; Accepted February 11, 2002)

\begin{abstract}
Recently, the separation between dispensing and prescribing drugs has made rapid progress and the number of pharmacists' jobs at hospitals have increased, which means that pharmacists are contributing more than ever to medical treatment. Thus the relation between the supply of and demand for pharmacists has become a topic in the improvement of pharmacist quality. In this study, we used date on pharmacists including type of job, registration number, etc. to predict the relation between the supply of pharmacists at work and the demand for pharmacists. In addition, we analyzed the working trends of pharmacy pharmacists and predicted the in relation between the supply and demand. Due to progress in the separation of dispensing and prescribing drugs, the supply of pharmacists will nearly equal demand temporarily. Howerer, the supply at work will always exceed demand, and we concluded that no shortage of pharmacists would occur. In addition, after the demand for pharmacists stops increasing, the excess supply of pharmacists will continue to increase. Based on analysis of working trends of pharmacy pharmacists, the in number will increase at the same rate as between 1996 and 1998 (approximately 6000 persons/year). Under this assumption, we concluded that no shortage of pharmacy pharmacists will occur, even if the separation of dispensing and prescribing drugs continues to accur at the rate of $5 \% /$ year.
\end{abstract}

Key words — supply and demand of pharmacists; separation of dispensing and prescribing drugs; working trends of pharmacy pharmacists

\section{はじめに}

近年, 医薬分業が急速に進展し，病棟における薬 剂師業務も一層の充実が図られ, 薬剤師がその任務 を果たす機会が増大してきている。 また，科学技術 の急速な進展に伴い医療が高度化し，国民の保健衛 生の向上に大きく貢献している一方で，医療事故が 社会問題化している。このような中, 薬剤師には, 高度な薬学の知識を背景とし，医療の担い手として の使命感や倫理感を持って, 医療へより積極的に貢 献することが期待されている。このため, 薬剤師の 資質の向上が求められており, 薬剤師養成に係る諸 問題につき「薬剤師養成問題懇談会」において, 関 係者の間で意見交換が行われているところである が，その中で薬剤師の需要と供給のバランスが検討

a) 厚生労働省, b) 財団法人日本薬剤師研修センター e-mail: yamamoto-nobuhiro@mhlw.go.jp
課題の 1 つになつている.

薬剂師の将来需給の予測に関しては, 平成 8 年度 厚生行政科学研究『あらたな薬剂師数の需給の予測 に関する研究』（主任研究者：内山充）において行 われているが, 本研究においては, 厚生労働省大臣 官房統計情報部が所持している薬剤師届出調査の届 出デー夕を，過去 10 年間にわたり詳細に解析する ことによって薬剤師の就業動向を解析し, 有職薬剂 師全体の需給関係と, 薬局薬剤師の就業動向並びに 需給予測を行うこととした。 なお，薬剂師届出調查 の届出デー夕は個人情報であり, 厚生労働省より持 ち出すことができないため, デー夕解析の操作は厚 生労働省において行った.

\section{解析方法}

薬剤師は 2 年毎に, 当該年末における氏名, 年 齢，住所そして職業など，厚生労働省令で定める事 項を厚生労働大臣に届け出なければならないとされ 
Table 1. Number of Pharmacists

\begin{tabular}{crrrrr}
\hline \hline Year & \multicolumn{1}{c}{1990} & \multicolumn{1}{c}{1992} & \multicolumn{1}{c}{1994} & \multicolumn{1}{c}{1996} & \multicolumn{1}{c}{1998} \\
\hline Pharmacy & 48596 & 52043 & 60499 & 69186 & 81043 \\
Hospital or Clinic & 41073 & 43279 & 45315 & 48362 & 48906 \\
College or Univ. & 2963 & 3142 & 5081 & 5652 & 6000 \\
Public Official & 4910 & 5144 & 5274 & 5411 & 5578 \\
Manufacturer, Importer or Sellor & 32576 & 37580 & 40677 & 44706 & 45692 \\
Others & 3924 & 4313 & 4585 & 4543 & 4241 \\
Inoccupation & 16040 & 16028 & 14477 & 14517 & 13963 \\
\hline
\end{tabular}

Table 2. Current Trend of Separation of Dispensing and Prescribing Drugs

\begin{tabular}{lrrrrr}
\hline \multicolumn{1}{c}{ Year } & 1990 & 1992 & 1994 & 1996 & 1998 \\
\hline $\begin{array}{l}\text { Nationwide average rate of } \\
\text { separating dispensing and prescribing function (\%) }\end{array}$ & 12.0 & 14.1 & 18.1 & 22.5 & 30.5 \\
Number pf prescriptions (1000 prescriptions) & 145733 & 178975 & 235013 & 296431 & 400061 \\
\hline
\end{tabular}

ている. この届出には, 薬剤師名簿登録番号が記入 されているため, この届出デー夕を解析することに より, 個人レベルで各々の薬剤師の就業動向を, 2 年毎に追跡することができる.

厚生労働省大臣官房統計情報部から提供された平 成 2 年〜平成 10 年の過去 5 回の薬剂師届出データ を精査したところ, 本来各回の調査で重複のないは ずの登録番号に，記入ミスなどによると思われるレ コード間の重複があった。これは解析の障害となる ので, 除外した。この結果, 解析の対象とするの は, 平成 2 年 150082 件, 平成 4 年 161529 件, 平成 6 年 175908 件, 平成 8 年 192377 件, 平成 10 年 205423 件のレコードとなった。 これらは, 統計情 報部に提出された届出データの件数より各年 $1 \%$ 前 後少なくなっているが, 薬剤師の就業動向の解析に は影響しないと判断した。

さて, 平成 2 年〜平成 10 年の過去 5 回に少なく とも 1 回の届出のある薬剤師 (以下, 「総届出薬剤 師」という。）は 261464 人であった。一方, 平成 10 年末までの薬剤師名簿登録番号は 336396 となつ ており, 免許取得時の年齢を 22 歳として単純に生 存率（厚生労働省大臣官房統計情報部『平成 11 年 簡易生命表』の生存数より算出）を乗ずることによ り生存している薬剤師数を粗く推計すると, 約 29 万人となった。 したがって, 本研究では, 生存薬剤 師の約 9 割を補足できているものと思われ, 需給予
測を行う上で十分であると考えた.

\section{現状分析}

職種別の薬剂師数に関しては, 薬局薬剂師が平成 8 年末から平成 10 年末において 11857 人増加して 81043 人となっていたのに対し，その他の職種は, おおむね同数となつていた（Table 1). 薬事関係の 業態数に関しては, 薬局数が平成 8 年末から平成 10 年末において 3775 施設増加し 44085 施設となつ ていたのに対し，他業態はおおむね同数あるいはや や減少していた. ${ }^{1)}$ 処方せん受取率は，近年急速に 上昇してきており, 平成 8 年度から平成 10 年度の 2 年間に $8 \%$ 増加し $30.5 \%$ となっており, また, 院外処方せん数も同時期において約 1 億枚増加し約 4 億枚となっていた（Table 2). ${ }^{2)}$

以上より, 医薬分業の進展に対応して, 薬局薬剤 師数及び薬局数が増加したと考えられ, 薬剤師需給 の予測の中でも薬局薬剤師の動向と需給予測が重要 な課題であることが分かる.

\section{薬剂師供給の推計}

1. 総薬剤師供給 まず, 薬剤師国家試験に合 格している者（以下，「総薬剤師」という.）の将来 推計を, 人口の推計等に一般的に用いられている コーホート要因法によって行った. ただし, 本研究 においては, 就業可能と思われる薬剂師供給を推計 するという観点から，90 歳以下の供給数を推計す ることとした. 
Table 3. Number of the Supply and Demand of Pharmacists

\begin{tabular}{cccccccc}
\hline \hline Year & 2002 & 2004 & 2006 & 2008 & 2010 & 2012 & 2014 \\
\hline Pharmacist & 287778 & 300916 & 313831 & 326512 & 338900 & 350898 & 362469 \\
Pharmacist at work & 220995 & 231426 & 240536 & 248864 & 257076 & 265028 & 272446 \\
The demand of pharmacist (Upper estimation) & 194639 & 215011 & 235847 & 238959 & 240920 & 242782 & 244872 \\
The demand of pharmacist (Lower estimation) & 184408 & 197460 & 210649 & 223897 & 236822 & 242782 & 244872 \\
\hline & & & & & & & \\
\hline & 2016 & 2018 & 2020 & 2022 & 2024 & 2026 & 2028 \\
\cline { 2 - 7 } & 373688 & 384621 & 394990 & 405001 & 414748 & 423904 & 432486 \\
& 279438 & 285724 & 291651 & 297271 & 302298 & 306874 & 310786 \\
& 245897 & 247190 & 247961 & 247837 & 247712 & 247168 & 246246 \\
& 245897 & 247190 & 247961 & 247837 & 247712 & 247168 & 246246 \\
\hline
\end{tabular}

コーホート要因法によると, $(\mathrm{t})$ 年の 12 月 31 日 現在の年齢 $(\mathrm{I})$ の男性薬剤師数を $\mathrm{Nm}(\mathrm{t}, \mathrm{I}),(\mathrm{t})$ 年に おける年齢 $(\mathrm{I})$ の男性の死亡確率を $\mathrm{Qm}(\mathrm{t}, \mathrm{I})$ ，そし て, $(\mathrm{t}+1)$ 年における年齢 $(\mathrm{I}+1)$ の男性の新規参入 薬剂師数を $\mathrm{Bm}(\mathrm{t}+1, \mathrm{I}+1)$ とすると, $\mathrm{Nm}(\mathrm{t}+1, \mathrm{I}$ $+1)$ は，次式で表される.

$$
\begin{aligned}
\mathrm{Nm}(\mathrm{t}+1, \mathrm{I}+1)= & \mathrm{Nm}(\mathrm{t}, \mathrm{I})-\mathrm{Qm}(\mathrm{t}, \mathrm{I}) \times \mathrm{Nm}(\mathrm{t}, \mathrm{I}) \\
& +\mathrm{Bm}(\mathrm{t}+1, \mathrm{I}+1)
\end{aligned}
$$

同様に，女性薬剂師について $\mathrm{Nf}(\mathrm{t}+1, \mathrm{I}+1)$ を計 算し，各年齢を通じての合計を求めれば, $(\mathrm{t}+1)$ 年 の薬剤師数を求めることができる.

推計の起点は, 総届出薬剂師とし, 年齢分布は平 成 10 年末における分布を用いた。 男女の死亡確率 は，厚生省大臣官房統計情報部「平成 11 年簡易生 命表」のデー夕を用い，推計期間中は一定と仮定し た。 新規参入薬剤師数は, 平成元年から平成 10 年 における薬剤師国家試験合格者の平均人数 8433 人/ 年とし, その男女比は, 平成 7 年から平成 10 年に おける薬科大学・薬学部卒業生の男女比の平均か ら，男性を $35 \%$ ，女性を $65 \%$ とし, ${ }^{3)}$ また，年齢 割合は，ある届出調査年に薬剤師登録番号を取得し た者の当該届出調査年における年齢割合を，過去 5 回の届出調査年においてそれぞれ求めて平均したも のを用い, 男女比, 年齢割合とも推計期間中は一定 と仮定した。ただし，41 歳以上の合格者は少数で あるため無視することとした。

以上により, 総薬剂師供給の推計を行った結果, 平成 20 年において約 327 千人，平成 30 年において 約 385 千人そして平成 40 年において約 432 千人と なった (Table 3).
2. 有職薬剤師供給 薬剤師需給を考える上で は，総薬剤師数の中の有職者（以下，「有職薬凨師」 という.）の推計を行うことが重要である.

有職薬剤師数は, 単純には総届出薬剂師に対する 平成 10 年末に有職として届け出た薬剤師の年齢別 の割合（以下，「有職届出率」という.）と総薬剂師 数の積と考えることもできるが, 実際には, 総届出 薬剂師のうち平成 10 年末に無届けであった者（以 下，「無届け者」という.）が約 56000 人存在してお り，この無届け者が有職かどうかを推定する必要が ある.

そこで，平成 10 年末無届け者の年齢分布を調べ たところ，20～30 代の女性が多くその割合も高か つた（Fig. 1)。これは, 結婚, 出産等に伴い離職 し届け出を行わなくなつた者がいるためだと考えら れる。一方，50 歳以降では男女で無届けである割 合に差が無く，高齢になるにつれて，割合も上昇し ていたが，これは，高齢になつたことにより離職 し，そのまま無届けになつたためであると考えられ る.このように，無届け者の人数やその割合が年齢 と性別に依存して顕著に変動していることが分か り，その動向から女性の無届け者の多くは無職であ ると考えられる。一方, 男性の無届け者が無職かど うかは, 平成 10 年末無届け者の年齢分布からは, 判断できない.

次に, 『国勢調査』(総務庁統計局) において求め られている男女別の就業者の割合を表す労働力率 (平成 7 年) と, 平成 10 年末における有職届出率を 比較したところ, 男性については 30〜60 代前半に おいて有職届出率は労働力率を $10 \%$ 以上下回って 


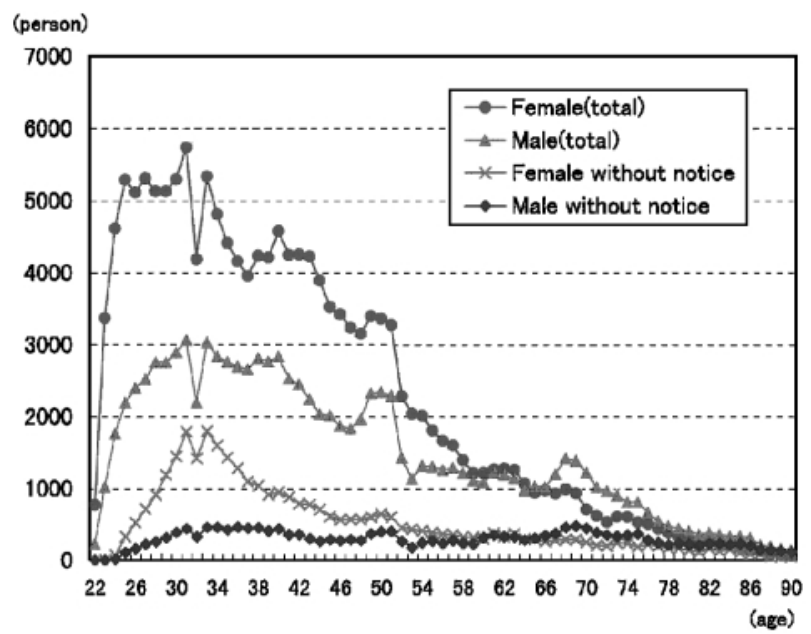

Fig. 1. Distribution of Pharmacists in 1998

"Female (total)" is the number of female pharmacists who submitted notification at least once between 1990-1998, and the same applies to "Male (total)". "Female without notice" is the number of female pharmacists who didn't submit notification in 1998, and the same applies to "Male without notice."

いた（Fig. 2).これは，30〜60 代前半において， 男性薬剂師の就業している割合が他の職種に比べて 低いというよりは，就業しているにも関わらず届出 をしていない者が相当数存在しているためであり, 男性の無届け者の中には有職者が相当数存在してい ると考えられる. 女性に関しては, 有職届出率は労 働力率をほぼ全年齢に渡って上回っており, 資格を 持つ女性がより高い割合で就業する傾向にあること が分かった。

ところで, 平成 2 年から平成 7 年にかけて, 女性 の労働力率は 25 歳以上で上昇傾向にあった. 現 在, 政府を挙げて少子化対策が推進されており, 今 後, 育児をしながらでも女性が働ける環境が整備さ れるにつれて, 女性の労働力率はより上昇すると予 測される. 女性薬剂師の有職届出率についても, 医 薬分業の進展に伴い薬局薬剂師の需要が増大してい ることも考慮すれば，今後，上昇すると予測される.

以上を考慮し, 有職届出率を, 男性については 30 50 代において平成 10 年度の值より $10 \%$ 上昇 させ，女性については，20４0 代において平成 10 年以降 $1 \%$ づつ 5 年間上昇させて, 有職率と仮定し た。なお， 60 代前半の男性においては, 有職届出 率, 労働力率ともに急速な減少傾向にあることか ら，その有職届出率は上昇させなかった，また，女 性の有職届出率に関しては, 上昇が予測されるもの

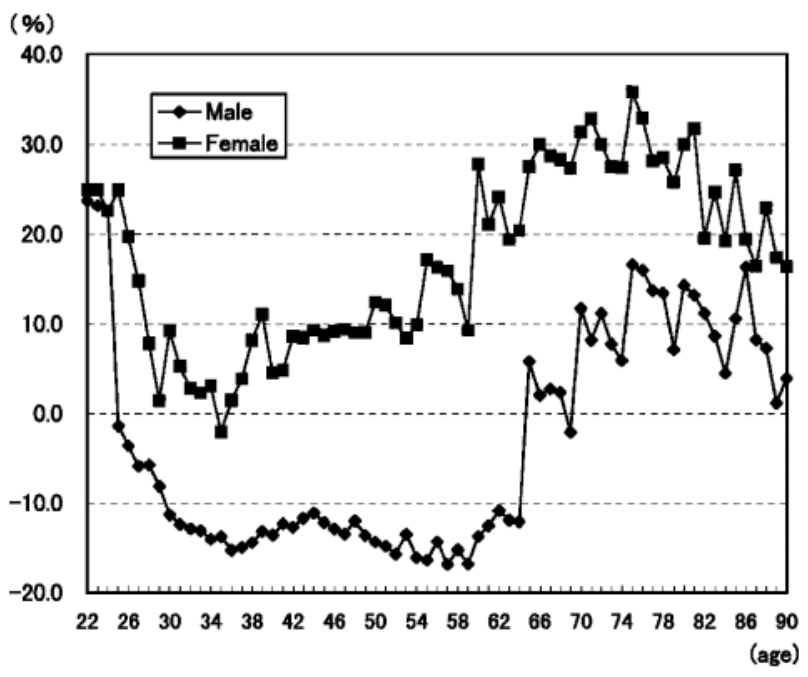

Fig. 2. Comparison between Ratio of Pharmacist at Work and Labour Force Ratio

Pharmacists at work are pharmacists who submitted notification as at work in 1998. Labour Force Ratio was calculated in national census in 1995 and covers all type of job. Figure 2 shows the results of subtracting Labour Force Ratio from Ratio of Pharmacist at Work.

の，その傾向がいつまでも続くとは考えられないた め，5年間に限定した。

この有職率を用い, 有職薬剤師数を推計したとこ ろ, 平成 20 年が約 249 千人, 平成 30 年が約 286 千 人そして平成 40 年が約 311 千人となった（Table 3, Fig. 3).

\section{薬剤師需要の推計}

薬剤師の職種は多岐にわたるため, 職種別に薬剤 師需要の推計を行つた.

1. 薬局薬剤師需要薬局薬剤師需要は, 薬局 における 1 年間の総取扱処方せん数の全国合計を, 薬局薬剂師 1 人が 1 年間に処理する処方せん数（以 下，「 1 人あたり枚数」という.）の平均値で割るこ とによって求められる.

薬局薬剂師需要 $=\frac{\text { 総取扱処方せん数の全国合計 }}{1 \text { 人あたり枚数 }}$

1-1. 総取扱処方世ん数薬局における総取扱 処方せん数は, 薬事法第 6 条第 1 項第 1 号の 2 の規 定に基づく「薬局及び一般販売業の薬剤師の員数を 定める省令」（以下，「員数省令」という.）におい て,「前年において取り扱つた眼科, 耳鼻咽喉科及 び歯科の処方せんの数にそれぞれ三分の二を乗じた 数とその他の診療科の処方せんの数との合計数」と 規定されている.

したがつて，総取扱処方せん数の全国合計は，眼 


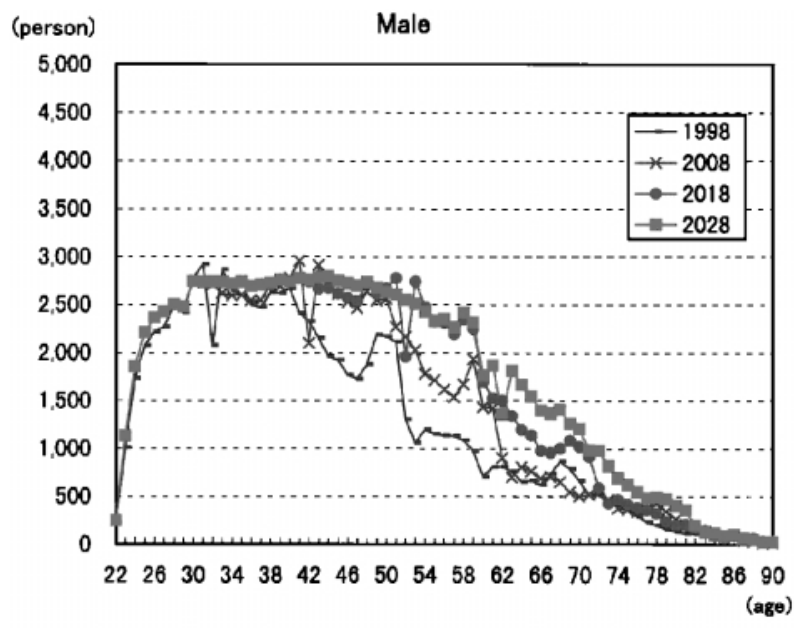

(a)

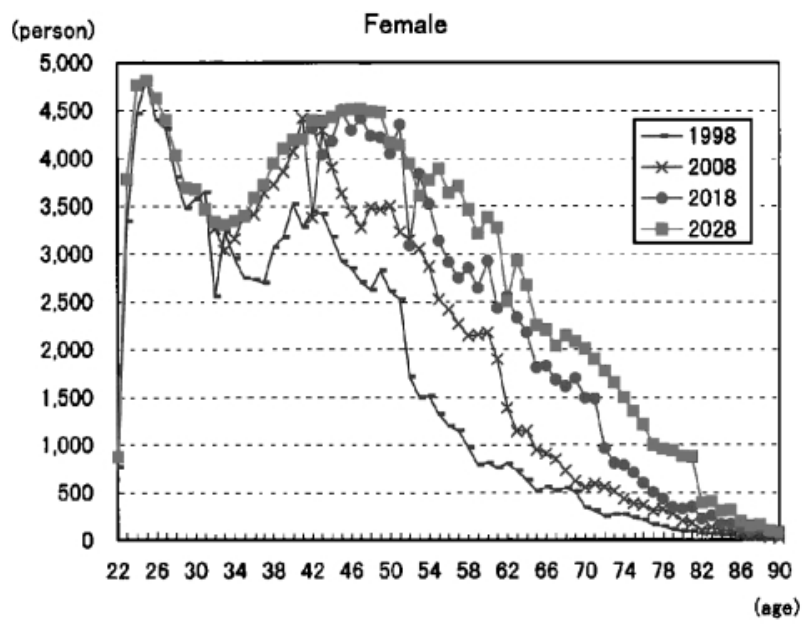

(b)

Fig. 3. Predicted Distribution of Pharmacists at Work

科，耳鼻咽喉科及び歯科（以下，「歯科等」という.) の外来投薬対象患者数に，歯科等における処方せん 受取率（以下，「歯科等処方せん受取率」という.） を乗じ，さらに $2 / 3$ を乗じた数と，歯科等以外の診 療科（以下，「医科」という.）の外来投薬対象患者 数に，医科における処方せん受取率（以下，「医科 処方せん受取率」という。）を乗じた数を加えるこ とによって，求めることができる，ただし，医科処 方せん受取率と歯科等処方せん受取率をそれぞれ求 めることはできないため, 本研究では全診療科の処 方せん受取率（以下，単に「処方せん受取率」とい う.）と同一と仮定した。 なお，この仮定が薬局薬 剂師需要に及ぼす影響は数百人程度であり，無視し ても差し支えない.

総取扱処方せん数
$=$ 歯科等外来投薬対象患者数

×歯科等処方せ九受取率 $\times 2 / 3$

十医科外来投薬対象患者数

×医科処方せん受取率

$\fallingdotseq($ 歯科等外来投薬対象患者数 $\times 2 / 3$

+ 医科外来投薬対象患者数）

×処方せん受取率

1 日あたり医科外来投薬対象患者数は，年齢階級 別将来推計人口数に年齡階級別医科外来患者受療率 を乗じ，さらに，医科投薬率（投薬率：外来患者の 診療実日数に対する投薬回数の割合）を乗じた数を 全年齢分加えることにより求められる。 また，1 日 あたり歯科等外来投薬対象患者数も同様に求められ る.

1 日あたり医科外来投薬患者数

$=\Sigma($ 年齢階級別将来推計人口

$\times$ 年齢階級別医科外来患者受療率

×医科投薬率 $)$

1 日あたり歯科等外来投薬患者数

$=\Sigma($ 年齢階級別将来推計人口

年齢階級別歯科等外来患者受療率

×歯科等投薬率)

年齢階級別将来推計人口は，『日本の将来推計人 口』（国立保障・人口問題研究所）の中位推計を用 いた。

年齢階級別外来患者受療率は, 平成 8 年『患者調 査』（厚生省大臣官房統計情報部）の「受療率（入 院一外来 $\times$ 性一年齢階級 $\times$ 傷病大分類別)」を用い, 今後，一定であると仮定した。歯科等の外来受療率 は，国際傷害疾病分類第 10 版 (ICD-10) における, 「う蝕」,「歯肉炎及び歯周疾患」,「その他の歯及び 歯の支持組織の疾患」,「白内障」,「その他の眼及び 付属器の疾患」, 「外耳疾患」, 「中耳炎」, 「その他の 中耳及び乳様突起の疾患」,「内耳疾患」及び「その 他の耳疾患」に係る外来受療率を加算して用いた。

投薬率は，『社会医療診療行為別調査報告』（厚生 省大臣官房統計情報部）における処方料及び処方せ ん料の算定件数の和を，入院外（全年齢）診療実日 数で割ることによって求められる. 平成 8 年から平 成 10 年について医科及び歯科における投薬率を計 算すると約 $66 \%$ 及び約 $12 \%$ となり, 今後, 一定で あると仮定した。眼科及び耳鼻咽喉科に係る投薬率 は統計值がなく求めることはできないため，歯科と 
同一であると仮定した。

以上により，1 日あたり医科外来投薬対象患者数 と 1 日あたり歯科等外来投薬対象患者数に $2 / 3$ 乗じ た数を合計した人数（この人数と, 外来投薬対象患 者全員に院外処方せんが発行された場合（処方せん 受取率 100\%）における，薬局の 1 日あたり総取扱 処方せん数は同じであることから, 以下，「最大取 扱処方せん数」という.）の推計を行った.

さて，1 年あたり最大取扱処方せん数を求めるた めには, 1 日あたり最大取扱処方せん数に 1 定日数 を乗じる必要があるが, 外来投薬対象患者数を求め る上で使用した受療率が平日における数值であるた め，単純に 365 日を乗じるのは適当ではない，そこ で，平成 10 年度のデー夕をもとに 1 日あたり最大 取扱処方せん数と, 1 年あたり最大取扱処方せ几数 の比率を求めることとした。まず，平成 10 年度の 年間処方せん受付枚数（薬局での受付回数）と処方 せ九受取率から平成 10 年度における最大取扱処方 せ九数を求めた。これを，平成 10 年における 1 日 あたり外来投薬対象患者数の推計值で割り, 約 329 を得た.この数值を一定と仮定して，1 日あたり最 大取扱処方せん数に乗じることにより, 各年の 1 年 あたり最大取扱処方せん数を推計した。

1 年あたり最大取扱処方せん数

$=1$ 日あたり最大取扱処方せん数

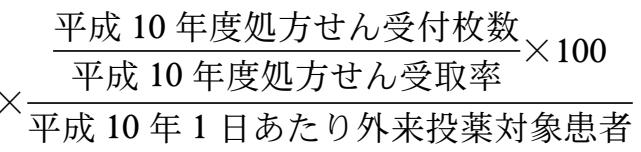

処方せ九受取率は, 平成 8 年度から平成 11 年度 にかけて平均約 4\%/年で上昇している.

処方せ几交付に関しては，医師法第 22 条におい て，医師が処方せんを発行しない場合も規定されて いることから，処方せん受取率には上限がある。ま た，医薬分業を原則としているアメリカにおいて， 処方せん受取率は約 80〜85\%といわれているが, 日本においては, 医薬分業の歴史が浅く, 薬は医者 から処方されるものという概念が根強く残つている ことなどを考慮すると，処方せん受取率はアメリカ より低い值で定常状態になると考えられる.

本研究においては, (1)上位推計（薬剂師需要が早 く上昇する仮定で行う推計）として処方せん受取率 の上昇を $5 \% /$ 年, (2)下位推計（薬剤師需要が遅く 上昇する仮定で行う推計）として処方せん受取率の
上昇を $3 \% /$ 年とし，いずれの場合においても $70 \%$ で定常状態になると仮定した。

1-2. 1 人あたり枚数 1 人あたり枚数は，処 方せん数（薬局での受付回数）の全国合計を, 薬局 薬剤師数で割ることによって求められる. 過去 5 回 の届出調査年における 1 人あたり枚数を求めた結 果, 平成 2 年から平成 10 年にかけて平均約 240 枚/ 年で増加しており, 平成 10 年においては 4926 枚で あった. また， 1 人あたり枚数を県別に求めた結果， 9000 枚を超える県から，2000 枚に満たない県まで 存在していた (Fig. 4). なお, 医薬分業の進展し ている県の方が，1 人あたり枚数が多い傾向があっ た.

薬局薬剂師の員数は, 員数省令において,「薬局 の薬剂師の員数は, 薬局における 1 日平均取扱処方 せん数が 40 までは 1 とし，それ以上 40 又はその端 数を増すごとに 1 を加えた数とする」と規定されて いることから， 1 人あたり枚数の上限は, 薬剤師が 週 5 日・年間 50 週労働し, 毎日 40 枚の処方せんを 取り扱うと仮定すると，10000 枚/年と考えられ る。しかし，実際には毎日効率よく処方せんを 40 枚処理することは難しく, また, 一般用医薬品の販 売等，調剤業務以外に費やされる時間も無視できな いため, 10000 枚/年処理することはできないと考 えられる。

一方, 医薬分業の先進地域である佐賀県, 秋田県 においては約 8000 枚となっており，これは薬剤師 が調剂以外の業務も行っている上での数值であると 考えられる.

そこで，本研究においては，1 人あたり枚数は平 成 10 年において全国平均が 4926 枚となっているも のの, 薬剤師 1 人が潜在的に処理できる処方せん数 を 8000 枚/年と仮定し, 需要予測を行うこととした.

1-3. 結果 以上により, 薬局薬剤師需要の推 計を行った結果, 平成 20 年において上位推計では 約 128 千人, 下位推計では約 114 千人となった。 平 成 23 年以降は, 処方せん受取率が定常状態に達す るため上位推計, 下位推計とも同数となり, 平成 30 年において約 136 千人, 平成 40 年において約 135 千人となった.

2. 病院 ·診療所薬剤師需要 病院 - 診療所薬 剂師数は, 平成 8 年末から平成 10 年末においてほ ぼ同数であり，平成 10 年末において 48906 人とな 
(\%)

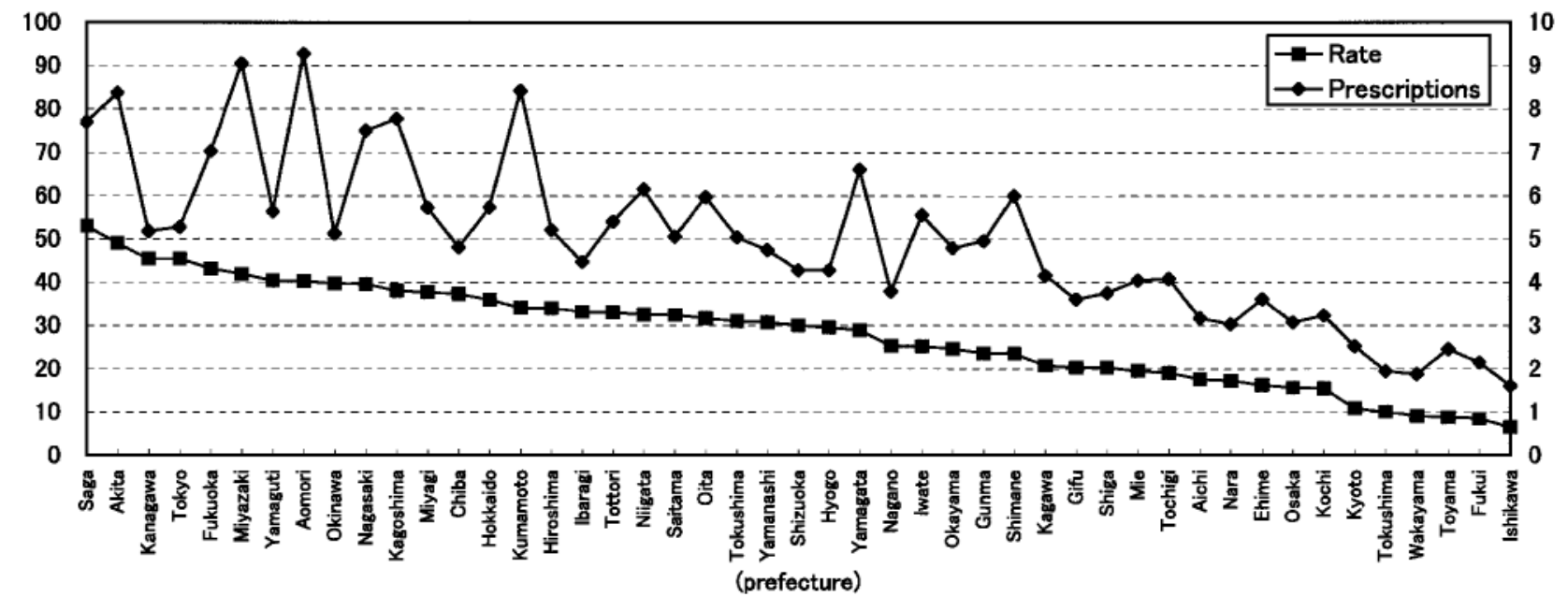

Fig. 4. Number of Average Prescriptions with which One Pharmacist Deals per Year and Rate of Separating Dispensing and Prescribing Function in 1998

つている.

これは, 医薬分業の進展に伴い, 病院・診療所薬 剂師が外来患者のために費やす労働力が減少した一 方で, 医療事故防止や医薬品の適正使用の推進のた め病棟における薬剤師業務の充実が図られた結果で あると考えられる.

今後もこのような傾向は続くと予測されるため, 本研究においては，49000人で一定であると仮定し た.

（注）平成 11 年度における病院の立ち入り検査 によると，医療法に定められた薬剤師数を遵守して いた病院は $82.9 \%$ となており, 現在の病院・診 療所薬剂師数では不足している可能性がある。しか しながら，先に述べたように医薬分業の進展に伴 い, 外来患者のために費やされる労働力が減少して いくことを考慮すると, 現在の病院・診療所薬剤師 数でも，遵守率は $100 \%$ 近く上昇すると考えられる.

\section{3. 教育研究従事者需要 教育研究従事者は,}

平成 2 年末から平成 10 年末において，約 3000 人で ほぼ一定となっているため，本研究においては， 3000 人で一定であると仮定した.

4. 大学院生需要 大学院生は平成 6 年末から 平成 10 年末にかけて, 平均約 220 人/年増加してお り, 平成 10 年末において 2930 人となっている. 増 加している理由として, 製薬企業等が修士卒業の学 生をより優先的に採用するようになってきているこ
となどが考えられるが，大学の受入能力にはいずれ 上限が生じると考えられる。

本研究においては, 今後, 220 人/年で増加し, その上限が 4000 人であると仮定した.

5. 衛生行政 ·保健衛生施設薬剂師需要 衛生 行政 - 保健衛生施設薬剂師数は, 平成 2 年末〜平成 10 年末にかけて平均で約 80 人/年づつ増加してお り，平成 10 年末において 5578 人であった。科学の 急速な進展等を考慮すると, 今後, 技術系公務員と しての役割はより重要になることが予想されるが, 定員には上限があると考えられる.

本研究においては, 今後, 80 人/年で増加し, そ の上限が 7000 人であると仮定した.

6. 一般販売業及びその他の販売業薬剤師需要 一般販売業及びその他の販売業勤務薬剂師数は平成 6 年末から平成 10 年末にかけて約 410 人/年で増加 しており, 平成 10 年末において 16247 人であつ た.一方, 業態数は平成 8 年末から平成 10 年末に かけて, やや減少していた。

一般販売業及びその他の販売業勤務薬剂師需要 は, 業態数そのものが今後飛躍的に増加するとは考 えにくいため，大きくは増大しないと予測される.

本研究においては, 今後 410 人/年で増加し, そ の上限が 18000 人であると仮定した.

7. 製造業勤務薬剤師需要 製造業勤務薬剤師 数は, 平成 8 年末から平成 10 年末においてほぼ一 定となっており, 平成 10 年末において 29445 人と 
なっている.

製造業勤務薬剤師需要は, 近年の科学技術の急速 な発展に伴い研究開発競争が激化していることか ら, 研究者としての薬剤師需要が今後高まる可能性 がある一方で，業務提携等に伴うスリム化も行われ ると考えられる。

本研究においては， 30000 人で一定であると仮定 した.

8. 結果以上により推計された各職種の薬剤 師需要数の総数 (以下, 「総薬剤師需要」という.) は, 平成 20 年において上位推計では約 239 千人, 下位推計では約 224 千人となった。平成 23 年以降 は, 処方せん受取率が定常状態に達するため上位推 計, 下位推計とも同数となり, 平成 30 年が約 247 千人, 平成 40 年が 246 千人となった。 また, 総薬 剂師需要の推計值は約 250 千人が上限であると予測 された（Table 3).

\section{有職薬剂師需給の予測}

有職薬剤師供給の推計值と総薬剤師需要の推計値 を比較した結果, 医薬分業の進展に伴う薬剤師需要 の増大により，一時的に供給数と需要数が接近する ものの, 常に供給数が需要数を上回っており, 薬剂 師不足が生じることはないと予測された（Fig. 5).

また, 需要が定常状態に達した後は, 過剩な薬剤師 が単調に増加することが分かった。

なお, 推計の初期数年間において, 有職薬剤師供 給数が総薬剤師需要数を上回っているのは, 薬局薬 剂師需要を推計するにあたり, 1 人あたりの処方せ 几処理枚数を平成 10 年末における平均処理枚数よ り多い 8000 枚/年と仮定したためである. したがつ て，過剩な薬剤師が存在しているというよりは，1 人 1 人の薬剤師がまだ余力を持って調剤業務等に取 り組んでいると考えられる。

\section{薬局薬剤師需給の予測}

医薬分業は今後も進展すると予測されていること から, 薬局薬剤師需給の予測を行うことは重要課題 である。

薬局薬剤師は, 平成 8 年末から平成 10 年末にお いて 11857 人増加しているが，このうち新卒後薬局 薬剤師となっている者は 3035 人であり，その他の 8822 人がどのような形で供給されているかは明ら かにされていない。 そこで, 薬局薬剤師供給の推計 を行うため, 薬局薬剤師の就業動向を解析した.

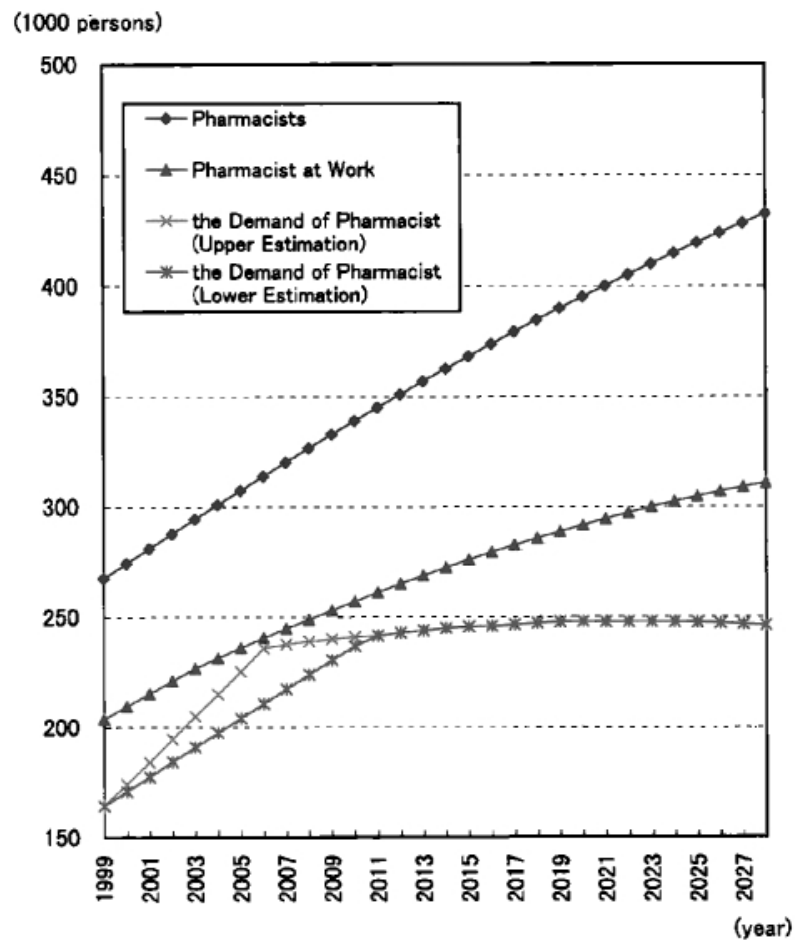

Fig. 5. Prediction of the Relation between the Supply and Demand of Pharmacists

\section{1. 薬局薬剤師の就業動向平成 8 年末に各職} 種に就業していた薬剤師の平成 10 年末における職 種を解析した。 その結果, 平成 8 年末薬局薬剤師 69186 人のうち, 平成 10 年末においても薬局勤務 を続けていた者は 54973 人であり, 14213 人が薬局 勤務を離れる一方，新たに 26070 人が薬局勤務とな つており，単純に 11857 人増加していた訳ではない ことが分かった。そこで，薬局勤務を続けていた者 （以下，「薬局勤務継続者」という.），薬局勤務を離 れた者（以下，「薬局勤務離職者」という。），そし て，新たに薬局勤務となった者（以下，「新規薬局 勤務者」という.）についてそれぞれ解析を行つた。

1-1. 薬局勤務継続者＼cjkstart薬局勤務継続者 54973 人 (男性 20762 人, 女性 34211 人) を解析した結果, 年齢別の割合は, 30 代前半から 40 代後半で男性が 女性より高く，それ以外の年齢では差がなかった。 また，年齢が高くなるにつれて，その割合も高くな る傾向が男女ともにあった（Fig. 6).

1-2. 薬局勤務離職者薬局勤務離職者 14213 人（男性 4206 人，女性 10007 人）を解析した結果, 薬局以外の職に転職している者は少なく，1487人 （約 10\%）が無職，8868人（約 62\%）が無届けと 


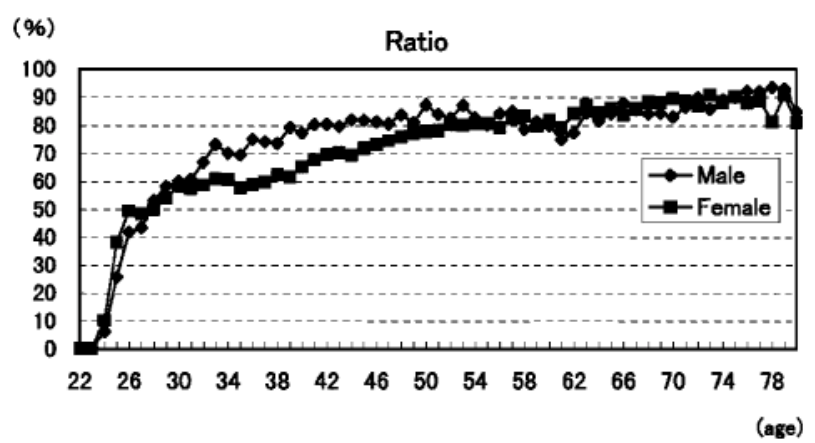

Fig. 6. Ratio of Pharmacists who Worked at Pharmacy in 1996 among Pharmacists who Worked at Pharmacy in 1998

なっていた. いずれも 20 代後半の女性が最も多く, 30〜 40 代の女性も多かった. また， 20 代後半の女 性に関しては, 薬局薬剤師から無届けあるいは無職 となった者の割合の合計が $30 \%$ 以上となってお り，高い割合で無届けあるいは無職となっているこ とが分かった（Fig. 7).

1-3. 新規薬局勤務者 新規薬局勤務者 26070 人（男性 7281 人，女性 18789 人）を解析した結果, これらの者の平成 8 年末における職種は主に, 病 院・診療所, 医薬品関連企業, 無職そして無届けで あり, 病院・診療所から 4341 人（男性 1104 人, 女 性 3237 人), 医薬品関連企業勤務から 3872 人（男 性 1476 人, 女性 2396 人), 無職から 1987 人（男性 171 人，女性 1816 人）そして無届けから 15166 人 （男性 4290 人，女性 10876 人）が新たに薬局勤務と なっていたことが分かった。また，新規薬局勤務者 は，20 代後半を中心とした 20〜 40 代の女性が多か った（Fig. 8)。なお，無届者の中には新規参入者 が約 3000 人含まれている.

平成 8 年末から平成 10 年末における薬局薬剂師 の就業動向の概要を（Fig. 9）に示す.

2. 各職種の就業動向上述の解析により, 薬 局薬剂師の就業動向を把握することができたが, 薬 局薬剂師供給の推計を行うためには, 薬局勤務離職 者や新規薬局勤務者が今後どのように推移するかを 予測する必要がある.

2-1. 薬局勤務離職者過去 5 回の届出調査に おいて薬局勤務を離れる割合を解析したところ，そ の割合はほとんど変化していなかったが, 薬局薬剤 師数自体が増加していたため, 薬局勤務を離れる人 数は増加していた．また，さきに述べたように薬局

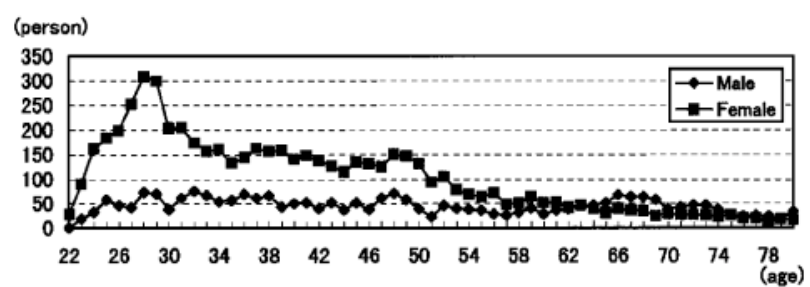

Fig. 7. Distribution of Pharmacists who Worked at Pharmacy in 1996 and didn't Submit Notification in 1998

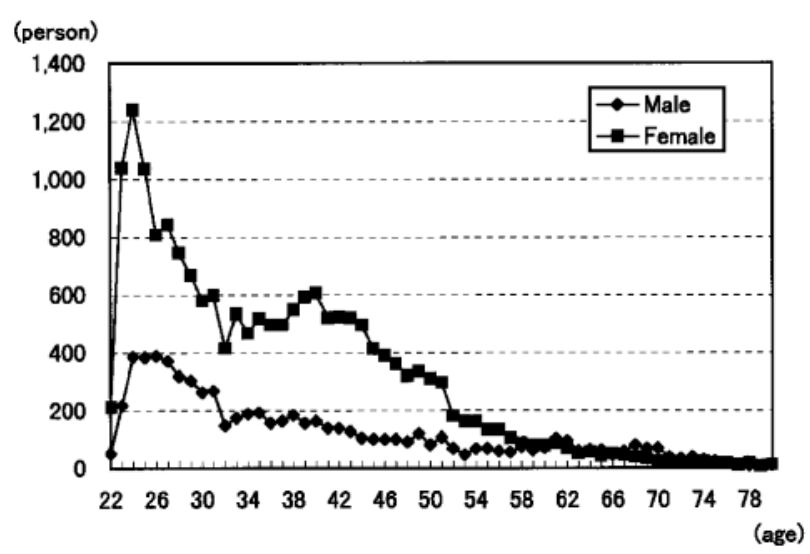

Fig. 8. Distribution of Pharmacists who didn't Work at Pharmacy in 1996 but Worked at Pharmacy in 1998

勤務を離れた者の多くは若い女性であり, 無職ある いは無届けとなっていることが多かったが，これ は, 結婚・育児等に伴い離職する女性が多いことが 理由であると考えられる.

今後は，「2. 有職薬剂師供給」において述べた ように, 結婚・育児等に伴い離職する女性は減少す ると考えられることから, 薬局勤務を離れる割合は 減少すると予測される。

2-2. 病院 ·診療所勤務から薬局への転職者 平成 8 年末から平成 10 年末における病院・診療所 勤務から薬局への転職者は, 20 代後半を中心とし た女性が多く, また, 薬局から病院・診療所への転 職者に比べ多かったが，同様の傾向は平成 4 年末か ら平成 6 年末, 及び平成 6 年末から平成 8 年末にお いても見られた。

新卒後病院・診療所に勤務する新卒者の数は, 年 によりやや差はあるものの, 平成 3 年以降はおおむ ね 1500 人〜 2000 人/年となっていた.

また, 過去 5 回の届出調査における年齢分布を解 析したところ，常に 20 代が多くなっており，20〜 


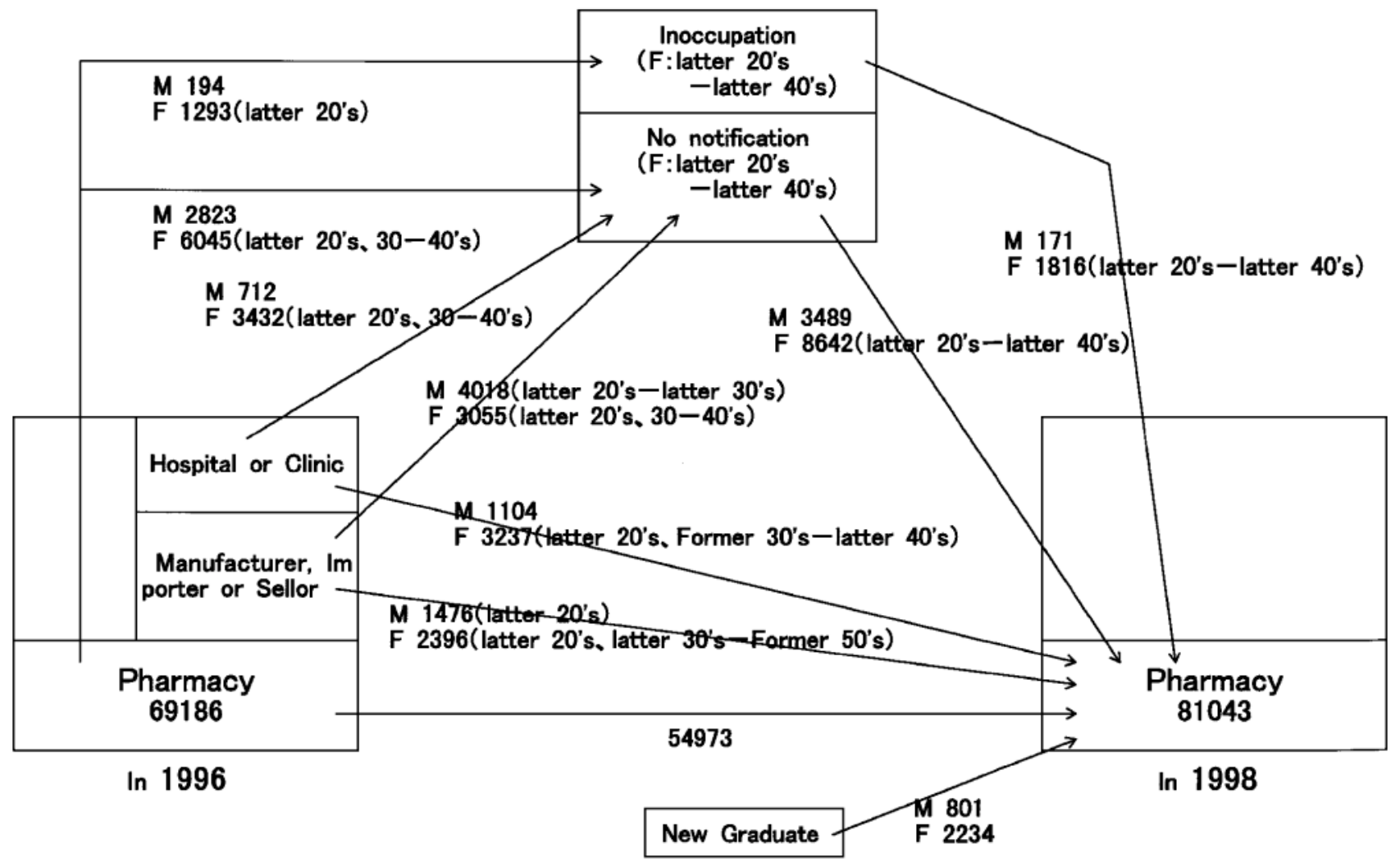

Fig. 9. Outline of the Working Trend of Pharmacy Pharmacist from 1996 to 1998

"F" represents female and 'M" represents male. F1293 (latter 20's) means that 1293 female pharmacists exist and latter 20's account for main portion of them.

30 代でほぼ変化しておらず，40 代では増加してい た (Fig. 10).

以上を考慮すると，新卒者が毎年一定数づつ病 院・診療所に勤務している一方で, 数年間勤務した 後に 20 代後半を中心とした女性が薬局へ転職する という傾向があり，そのため，20３0 代における 年齢分布が変化していないと考えられる. 今後も一 定数の新卒者が病院・診療所に勤務することが見込 まれる一方で,「2. 病院·診療所薬剂師需要」に おいて述べたように病院・診療所薬剤師需要は一定 であると予測されることから，この傾向は変化しな いと考えられる。したがって, 病院・診療所勤務か ら薬局への転職者は引き続き存在すると予測される.

\section{2-3. 医薬品関連企業勤務から薬局への転職者} 平成 8 年末から平成 10 年末における医薬品関連企 業勤務から薬局への転職者は, 薬局から医薬品関連 企業への転職者と比べ多かつたが，同様の傾向は平 成 4 年末から平成 6 年末, 平成 6 年末から平成 8 年 末においても見られた。
新卒後医薬品関連企業に勤務する者の数は減少傾 向にあり, 平成 3 年と比べると平成 10 年は約半数 の 1792 人となっていた。 そのため, 医薬品関連企 業薬剂師数は, 平成 2 年末から平成 8 年末において 平均 2022 人/年で増加していたが，平成 8 年末から 平成 10 年末にかけてほとんど変化していなかった.

また, 過去 5 回の届出調査における医薬品関連企 業勤務薬剂師の年齢分布を解析したところ，高齢側 にシフトしていた（Fig. 11）。

以上を考慮すると，新卒後医薬品関連企業に就職 する者が多かつた時は, 薬局への転職者も存在して いたものの, 医薬品関連企業薬剤師数は増加してい たが, 新卒後医薬品関連企業に就職する者が減少 し，薬局への転職者が多くなるにつれて，年齢分布 は高齢側にシフトし, 医薬品関連企業薬剤師数はほ とんど変化しなくなったと考えられる.

今後, 新卒後医薬品関連企業に勤務する者が大き く増加することは見込まれず，また，転職者の多い 年代における医薬品関連企業薬剂師数が減少してい 


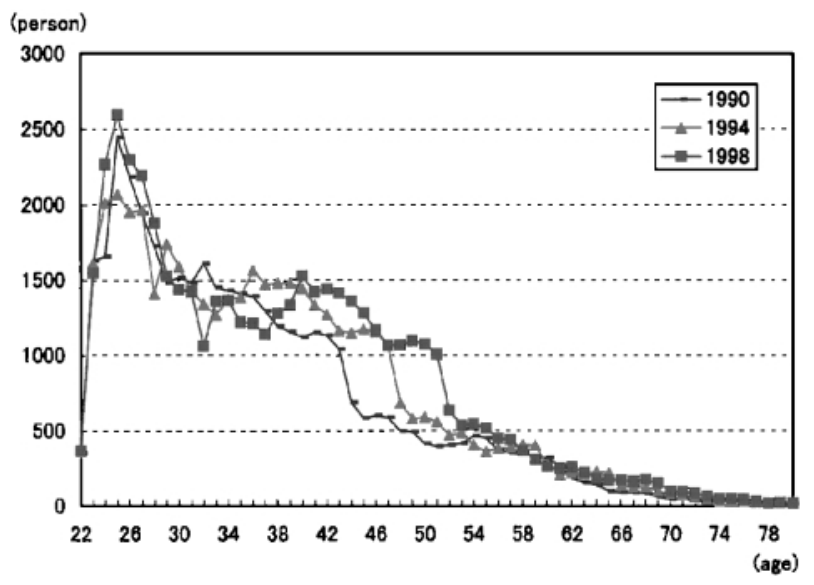

Fig. 10. Distribution of Pharmacists who Worked at Hospital or Clinic in 1990, 1994 and 1998

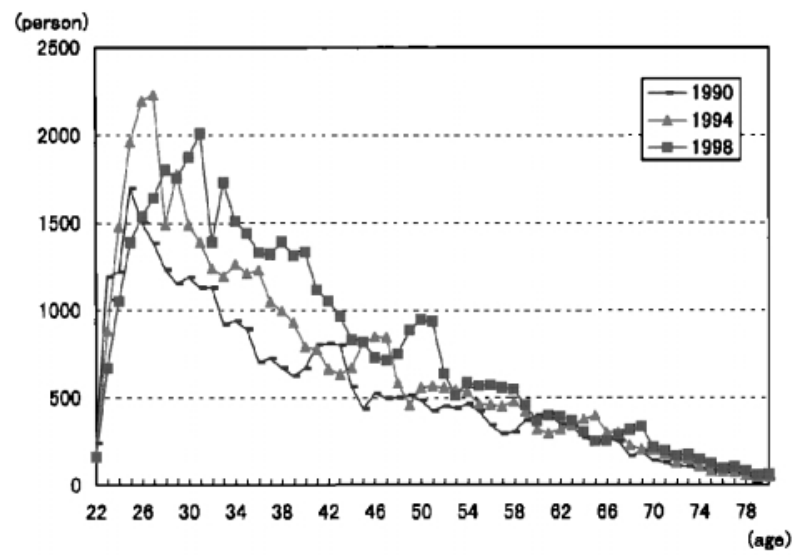

Fig. 11. Distribution of Pharmacists who Worked at Manufacturer, Importer or Seller in 1990, 1994 and 1998

るため, 医薬品関連企業勤務から薬局への転職者は やや減少すると予測される.

2-4. 新卒者薬科大学 (薬学部) 卒業後, 薬 局に就職する人数は増加傾向にあり，平成 9 年 3 月 卒業者のうち 1472 人, 平成 10 年 3 月卒業者のうち 1563 人そして平成 11 年 3 月卒業者のうち 2026 人 が卒業後薬局薬剤師になっていた.

医薬分業の進展に伴い薬局薬剤師需要は今後も増 大すると見込まれており，薬局への就職を阻害する 要因は特に見当たらないことから, 新卒後薬局薬剤 師になる者は引き続き存在すると予測される.

\section{2-5. 無届け者過去 5 回の届出調査における} 無届け者の年齢分布は, 新卒者の影響を除くとおお むね変化していなかった，また, 薬局, 病院・診療 所そして医薬品関連企業等から無届けとなる割合は おおむね変化していないものの, 各職種の人数自体
が増加しているために，その人数は増加してきてい る.したがって，薬局薬剤師等が無届けとなる人数 が増加している一方で, 薬剤師需要の増大を受けて 無届けから再就職する者も増加したために, 結果と して年齢分布はおおむね変化しなかったと考えられ る.

無届けから薬局へ再就職する人数は増加傾向にあ り，この傾向を阻害する要因は見当たらないことか ら, 無届け者から薬局へ再就職する者は引き続き存 在すると予測される.

ところで，平成 8 年末から平成 10 年末におい て, 病院・診療所あるいは医薬品関連企業から無届 けあるいは無職となっている 20〜 40 代の女性が 6650 人存在していた。無届けとなっている者の多 くは無職となっていると考えられるが，先に述べた ように今後離職する女性の割合は減少すると予測さ れる。近年, 病院・診療所あるいは医薬品関連企業 から薬局へ転職する傾向があることを考慮すれば, 病院・診療所あるいは医薬品関連企業から離職する 代わりに，薬局に転職する女性が増加すると予測さ れる。

3. 需給予測 以上をまとめると, 平成 8 年か ら平成 10 年末における薬局薬剤師の増加は, 病 院・診療所や医薬品関連企業からの転職者, 無届け からの再就職者そして新卒者により補われていた。 そして, 薬局勤務離職者は減少し, 病院・診療所か らの転職者, 無届けからの再就職者そして新卒者は 引き続き存在し, 医薬品関連企業からの転職者は減 少する可能性があるものの, 病院・診療所あるいは 医薬品関連企業から離職する代わりに薬局に転職す る女性が増加すると予測された。これらを考慮し, 本研究においては, 薬局薬剂師は平成 8 年末から平 成 10 年末における薬局薬剂師数の増加ペース （5929人/年）で増加し得ると仮定して薬局薬剤師 の推計を行い, 先に求めた薬局薬剤師需要の推計值 と比較して, 薬局薬剤師需給の予測を行った。

その結果, 医薬分業の進展に伴う薬局薬剤師需要 の増大により, 一時的に供給数と需要数が接近する ものの, 常に供給数が需要数を上回っており, 薬局 薬剂師不足が生じることはないと予測された（Fig. 12).

ここで, 薬局薬剤師供給は平成 8 年末から平成 10 年末におけるペースで増加すると仮定している 


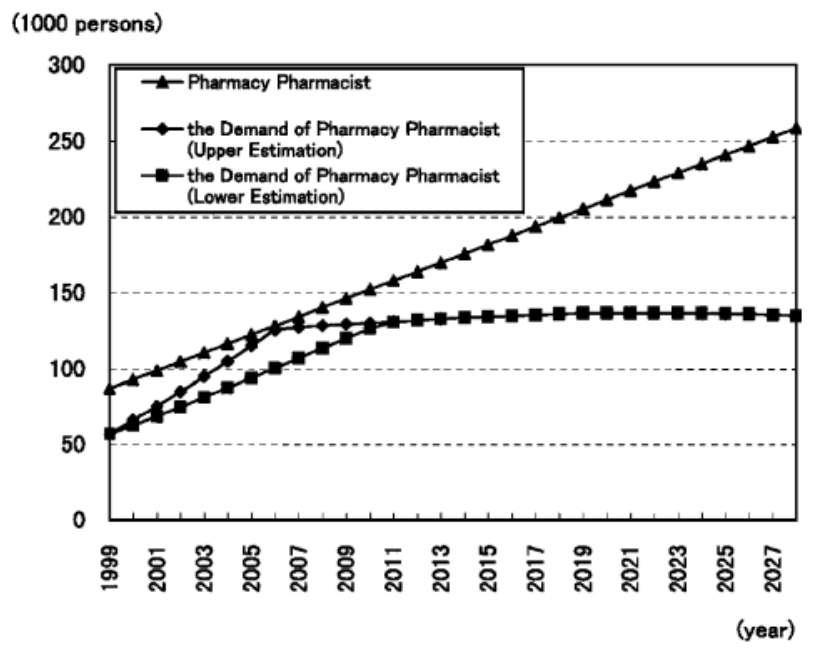

Fig. 12. Prediction of the Relation between the Supply and Demand of Pharmacy Pharmacist

が, これは医薬分業の進展に伴い薬局薬剤師需要が 増加しているためにこのペースで増加すると仮定で きるのであり, 処方せん受取率が定常状態に達し薬 局薬剤師需要が頭打ちになれば, 増加ペースは減少 すると予測される.

\section{薬剤師国家試験受験資格の見直しと薬剤師需給}

先に述べたように, 現在, 薬剤師の質の向上が求 められているが，仮に薬剤師の資質の向上などへの 社会的要請に応えて, 6 年間の薬学教育を修了した 者にの夕薬剤師国家試験の受験資格を与えるとの見 直しを行った場合, それに対応して薬剤師国家試験 の難易度が上昇することなどにより, 合格者数が減 少し, 薬剤師不足が生じる可能性があると懸念され る.

そこで，仮に上述の見直しを行い，その結果，国 家試験合格者が減少した場合における, 有職薬剤師 需給の予測を行うこととした.

実際に受験資格の見直しを行うにあたっては，学 生への周知期間や大学側の受入体制整備のために数 年を要すると考えられるため, 平成 21 年, 平成 23 年そして平成 25 年より 6 年間の薬学教育修了者に のみ国家試験受験資格を与えると仮定した。また, それぞれの場合において, 国家試験合格者数（新規 参入薬刘師数）がそれまでの 9 分の 8,9 分の 7,9 分の 6 そして 9 分の 5 に減少すると仮定し, その年 齢分布比率はそれまでの年齢比率を 2 歳高齢側にシ フトさせた. また, 受験資格の見直しを行う年の前
2 年間は新規卒業者が生じないが，平成元年から平 成 10 年において，国家試験不合格者の存在などに より新卒者以外の国家試験合格者が平均 1177 人/年 存在しており，その合格率が約 50\% であったこと から, 新規卒業者が途絶える 1 年目の年に 1177 人, 2 年目の年に 588 人の国家試験合格者が存在すると 仮定した.

以上により，有職薬剤師需給の予測を行つた結 果, 平成 21 年から受験資格の見直しを行った場 合, 平成 20 年頃において薬剤師不足が生じる可能 性があるが, 平成 23 年あるいは平成 25 年から受験 資格の見直しを行う場合には，薬剤師不足は生じな いと予測された。また，合格者が 9 分の 8 あるいは 9 分の 7 に減少すると仮定した場合は, 増加速度は 減少するものの有職薬剂師供給数は増加傾向にあ り, 将来的には過剩な薬剤師が単調に増加すると予 測された。一方, 9 分の 6 あるいは 9 分の 5 に減少 すると仮定した場合は, 有職薬剂師数はおおむね定 数となり, 薬剤師需要と適正なバランスを保ち, 過 剰な薬剤師が単調に増加することはないと予測され た (Fig. 13).

なお，新規卒業者が生じない 2 年間において有職 薬剂師数が減少しているが, これは, 薬剤師供給数 を 90 歳以下で計算しているために推計の対象から 離れる者がいること，亡くなられる方がおられるこ と, 及び, 新規参入薬剤師が大きく減少することに より薬剤師の平均年齢が約 2 歳高齢側にシフトし, 全体の有職率が低下することが原因である.

\section{考察}

本研究は, 薬剤師届出調査の届出デー夕を使用す ることによって薬剤師の就業動向を解析し, 有職薬 剂師全体の需給関係と, 薬局薬剤師の就業動向並び に需給の予測を行った。

有職薬剤師の推定は, 届出データから求められた 有職届出率をべースとし, 国勢調査の労働力率も勘 案して求めた有職率を利用したことにより，信頼性 を高めることができた。

有職薬剤師需給については, 医薬分業が処方せん 受取率にして $5 \%$ / 年で進展した場合, 有職薬剤師 数と薬剤師需要数が一時的に接近すると予想された が，現状の実績が約 4\% であることを考えれば，実 際には処方せん受取率が $5 \% /$ 年で単調に $70 \%$ まで 上昇し続けることは難しく, 本研究で示したほど薬 


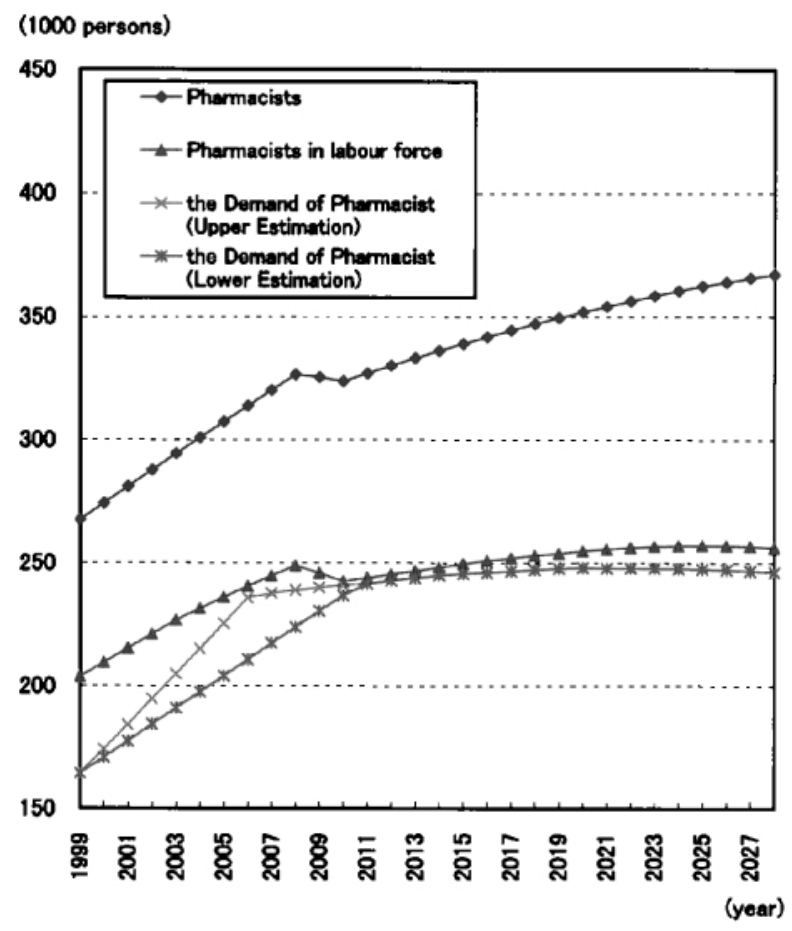

Fig. 13. Prediction of the Relation between the Supply and Demand of Pharmacists, under the Assumption that Students who Finish 6-Year-Education are Allowed to Take the National Examination from 2011, and that Number of Successful Applicant Decreases to Two-Third

剤師供給が逼迫することはないと考えられる。

薬局薬剤師需給の予測にあたつては, 薬局薬剤師 の就業動向の解析などから, 薬局薬剤師は平成 8 年 末から平成 10 年末におけるペースで増加すると仮 定したが, 今後, 薬剤師需要が大きく伸びるのは薬 局だけであり，職種間で様々な移動があるにせよ， 総薬剂師数の増加分の大半は, 最終的には薬局薬剤
師の増加でしか吸収され得ないと考えられることか らも，無理のない仮定である.

また, 薬局薬剂師の就業動向の解析などから, 女 性の薬剤師が，結婚・育児などに伴い離職する一方 で，育児などが落ち着いた後に再就職する傾向があ ることが示されたことから，女性が育児などを行い ながらでも働ける環境を整えることが薬剤師を確保 する 1 つの方法であろう.

近年, 薬剤師不足が叫ばれているが, 本研究によ れば現在でも薬剤師数には余裕があり, 薬剤師不足 は薬剤師の絶対数が不足しているためではなく, 専 門的職能の発揮が不十分であったり, 雇用条件の不 一致などにより薬剤師確保が困難となっていること などが主な原因ではないかと考えられる.

近い将来，薬剤師が過剩になると予測されたこと を踏まえ, 薬剤師の量の確保に取り組むよりは, 薬 剂師により高度な職能が求められていくことを考慮 して, 薬剤師の質の向上に早急に取り組むことが重 要であると考える.

\section{REFERENCES}

1) Ministry of Health and Welfare, Pharmaceutical and Medical Safety Bureau 『Yakuji Kankei Gyotaisu Chosa』1996 1998.

2) Japan Pharmaceutical Association 『Hoken Chozai no Doukou』1996 1998.

3) Yakugaku Kyoiku Kyogikai『Yakka Daigaku Sotsugyousei Shugyo Doukouchosa no Shukei Houkoku』1995 1999. 